Pacific Journal of Mathematics

DEFICIENCIES OF IMMERSIONS 


\section{DEFICIENCES OF IMMERSIONS}

\section{URI SREBRo}

\section{Dedicated to Steve Warschawski}

Let $X$ and $Y$ be manifolds of the same dimension $n \geq 2$ and let $f$ : $X \rightarrow Y$ be an immersion with $p=\sup \{n(y): y \in Y\}<\infty$ where $n(y)$ $=$ cardinality $f^{-1}(y)$. If $Y$ is compact and $X$ is not, then $n(y)<p$ for some $y \in Y$, see $\$ 2$. If $Y$ is compact and simply connected and $p \geq 2$, then $Y$ contains a compact set $E$ such that $Y-E$ is not simply connected and $n(y) \leq p-2$ for all $y \in E$, see $\S 5$.

1. THEOREM. Let $X$ be a non-compact $n$-manifold, $Y$ a compact $n$-manifold and $f: X \rightarrow Y$ an immersion. If $p=\max _{y \in Y} n(y)<\infty$, then $n(y)<p$ for some points $y \in Y$. In particular, if $y=\lim _{k \rightarrow \infty} f\left(x_{k}\right)$ for an infinite sequence of distinct points $x_{k} \in X$ which does not accumulate in $X$, then $n(y)<p$.

Proof. Suppose that $n(y)=p$ with $f^{-1}(y)=\left\{a_{1}, \ldots, a_{p}\right\}$. Choose disjoint closed cells $U_{i}$ in $X$ such that $a_{i} \in$ int $U_{i}$ and such that $f \mid U_{i}$ is injective for $1 \leq i \leq p$. Then $x_{k} \notin \cup U_{i}$ for almost all $k$. Now choose a neighborhood $V$ of $y$ such that $V \subset \cap_{i=1}^{p} f\left(U_{i}\right)$ and let $V_{i}$ denote the $a_{i}$ component of $f^{-1}(V)$. Then $f$ maps each $V_{i}$ homeomorphically onto $V$ and hence $n\left(y^{\prime}\right)=p$ for all $y^{\prime} \in V_{0}$. It thus follows that $f\left(x_{k}\right) \notin V$ for all $x_{k}$ in $X_{0}=X-\cup V_{i}$, that is for almost all $x_{k}$. Hence $f\left(y_{k}\right) \nrightarrow y$, contradicting the assumption $f\left(x_{k}\right) \rightarrow y$, and thus $n(y)<p$.

2. REMARK. For compact manifolds $X$ with boundary Theorem 1 says that $n(y)<p$ for every $y$ in the cluster set of $f$ on $\partial X$. This contains a result of Brannan and Kirwan [1, Theorem 1] as a special case.

3. Suppose that $X$ is non-compact, that $Y$ is compact and that $1<p=\max n(y)<\infty$. We say that $f$ has a deficiency at a point $y \in Y$ if $n(y) \leq p-2$. The set $A=\{y \in Y: n(y) \leq p-2\}$ will be called the deficiency set of $f$. It is not hard to construct immersions, for instance of $S^{1} \times R$ into $S^{1} \times S^{1}$ with empty deficiency set. The purpose of this note is to show that if $Y$ is simply connected, then the deficiency set $A$ is non-empty and, in fact, it is quite large. 
4. TheOREM. Let $X$ be an n-manifold and $Y$ a simply connected compact $n$-manifold, $n \geq 2$, and let $f: X \rightarrow Y$ be an immersion with $1<p=$ $\max n(y)<\infty$. Then the deficiency set $A$ contains a compact subset $E$ such that $Y-E$ is not simply connected.

5. REMARK AND NOTATION. The proof is based on two elementary lemmas and on application of the monodromy theorem to a certain extension of $f$. The extension of $f$ is essentially the same as in Lyzzaik and Styer [2, §2]. The following notation will be used: For $r>0$ and $a \in R^{n}$, $B^{n}(a, r)=\left\{x \in R^{n}:|x-a|<r\right\}, B^{n}(r)=B^{n}(0, r), B^{n}=B^{n}(1)$ and in particular $B^{2}=\{z \in \mathbf{C}:|z|<1\}$. We say that a compact set $E$ in a simply connected space $Y$ is $\pi_{1}$-negligible if $Y-E$ is simply connected. In this notation, Theorem 4 asserts that the deficiency set $A$ has compact subsets which are not $\pi_{1}$-negligible in $Y$.

6. LEMMA. Let $H: \bar{B}^{2} \rightarrow R^{n}$ be a continuous function with $H(-1) \in B^{n}$ and $H(1) \notin \bar{B}^{n}$. Then $H^{-1}\left(\partial B^{n}\right)$ contains a continuum $C$ which meets both components of $\partial B^{2}-\{-1,1\}$.

Proof. By the Jordan separation theorem $F=H^{-1}\left(\partial B^{n}\right)$ separates the points -1 and 1 in $\bar{B}^{2}$. Let $B_{1}$ denote the connected component of $\bar{B}^{2}-F$, which contains the point -1 , and let $B_{2}$ be the connected component of $\mathbf{C}-B_{1}$, which contains the point 1 . Then $C=\partial B_{2} \cap \bar{B}^{2}$ is the desired continuum.

7. LemMa. Let $A$ be a closed set in $R^{n}$. If every compact subset $E$ of $A$ such that $R^{n}-E$ is connected is $\pi_{1}$-negligible then

(i) int $A=\varnothing$.

(ii) $U=R^{n}-A$ is connected.

Proof. (i) is trivial.

(ii) Suppose that $U$ is not connected. Choose points $a_{1}$ and $a_{2}$ which belong to different connected components of $U$. Since $A$ is closed there is $r>0$ such that $B^{n}\left(a_{i}, 2 r\right) \subset U, i=1,2$. Let

$$
G=\bigcup_{0 \leq t \leq 1} B^{n}\left(t a_{1}+(1-t) a_{2}, r\right)
$$

and $E=A \cap \partial G$. Now choose points $b_{i} \in \partial B\left(a_{i}, 2 r\right), i=1,2$, so that $a_{1}$, $a_{2}, b_{1}, b_{2}$ are vertices of a rectangle $R$. Since $R^{n}-E$ is simply connected, 
there is a continuous function $H: \bar{B}^{2} \rightarrow R^{n}-E$ mapping $\partial B^{2}$ homeomorphically onto $R$. We may assume that $H(-1)=a_{1}, H(1)=b_{1}, H(i) \in$ $\partial B^{n}\left(a_{1}, r\right)$ and $H(-i) \in \partial B^{n}\left(a_{2}, r\right)$. By Lemma 6 there exists a continuum $C$ in $H^{-1}(\partial G)$ joining the components of $\partial B^{2}-\{-1,1\}$. Hence $C^{\prime}=H(C)$ is a continuum in $\partial G$ joining $\partial^{n} B\left(a_{1}, r\right)$ and $\partial^{n} B\left(a_{2}, r\right)$. Hence $a_{1}$ and $a_{2}$ can be joined by a continuum in $U$, contradicting the assumption that $U$ is not connected.

8. Proof of Theorem 4.. Let $A_{k}=\{y \in Y: n(y)=k\}$. Then $A_{p}$ and $A_{p} \cup A_{p-1}$ are open and hence the deficiency set $A=Y-\left(A_{p} \cup A_{p-1}\right)$ is compact. Consider the disjoint union $\tilde{X}=X \cup A_{p-1}$ with the topology containing the topology of $X$ and the topology of int $A_{p-1}$, which makes the extension $\tilde{f}: \tilde{X} \rightarrow Y$ of $f, \tilde{f}(x)=f(x)$ for $x \in X$ and $\tilde{f}(x)=x$ for $x \in A_{p-1}$, a local homeomorphism. Obviously, $\tilde{f}$ is a local homeomorphism in $X \cup$ int $A_{p-1}$. For $y \in \bar{A}_{p} \cap A_{p-1}$ with $f^{-1}(y)=\left\{x_{1}, \ldots, x_{p-1}\right\}$ choose disjoint cells $U_{i}$ in $X$ with $x_{i} \in$ int $U_{i}$ and such that each $f \mid U_{i}$ is injective, $1 \leq i<p$. Now let $V$ be an open set in $\cap f\left(U_{i}\right)$ containing $y$. Then $\tilde{f}$ maps $U_{0}=f^{-1}(V)-U U_{i}$ homeomorphically onto $V \cap A_{p}$ and $\tilde{f}$ maps $U=U_{0} \cup\left(V \cap A_{p-1}\right)$ injectively onto $V$. Such sets $U$ form a base of neighborhoods of $y \in \bar{A}_{p} \cap A_{p-1}$.

Suppose now that Theorem 4 is false, i.e., all compact subsets $E$ of $A$ such that $Y-E$ is connected are $\pi_{1}$-negligible in $Y$. Then obviously int $A=\phi$. Also, if $D$ is an open cell in $Y$, then, by Lemma 7, $D-A$ is connected. Since every two points $a$ and $b$ in $Y$ can abe connected by a chain of open cells $D_{1}, \ldots, D_{k}$ such that $a \in D_{1}, b \in D_{k}$ and $D_{i} \cap D_{i+1} \neq$ $\varnothing$ for $1 \leq i<k$, it follows that $Y-A$ is connected and hence so is $X_{0}=\tilde{X}-f^{-1}(A)$. Now $X_{0}$ is a manifold and $f_{0}=\tilde{f} \mid X_{0}$ is a $p$ to 1 covering map of $X_{0}$ onto $Y-A$. The assumption that $Y-A$ is simply connected implies, by the monodromy theorem, that $f_{0}$ is injective and hence that $p=1$. This contradiction completes the proof.

9. REMARK. For $n=2$ Theorem 4 says that the deficiency set of an immersion of a non-compact surface into $S^{2}$ has at least two points. This contains a reuslt of Brannan and Kirwan [1, Theorem 2] as a particular case.

10. Acknowledgement. I wish to thank Mike Freedman, Brit Kirwin and Joe Wolf for helpful discussions. 


\section{REFERENCES}

[1] D. A. Brannan and W. E. Kirwan, Some covering theorems for analytic functions, J. London Math. Soc., (2) 19 (1979), 93-101.

[2] A. Lyzzaik and D. Styer, A covering surface conjecture of Brannan and Kirwan, Bull. London Math. Soc., 14 (1982), 39-42.

Received May 21, 1982.

TECHNION HAIFA

TECHNION City, 32000 HAIFA, ISRAEL

AND

University of California, San Diego

LA Jolla, CA 92093 


\section{PACIFIC JOURNAL OF MATHEMATICS \\ EDITORS}

Donald BaBBITT (Managing Editor)

University of California

Los Angeles, CA 90024

Hugo RossI

University of Utah

Salt Lake City, UT 84112

C. C. Moore and Arthur Ogus

University of California

Berkeley, CA 94720
J. DugundiI

Department of Mathematics

University of Southern California

Los Angeles, CA 90089-1113

R. FINN and H. SAMELSON

Stanford University

Stanford, CA 94305

\section{ASSOCIATE EDITORS}
R. ARENS
E. F. BECKENBACH
B. H. NeUMANN
F. WOLF
K. YoshidA (1906-1982)

\section{SUPPORTING INSTITUTIONS}

\author{
UNIVERSITY OF ARIZONA \\ UNIVERSITY OF BRITISH COLUMBIA \\ CALIFORNIA INSTITUTE OF TECHNOLOGY \\ UNIVERSITY OF CALIFORNIA \\ MONTANA STATE UNIVERSITY \\ UNIVERSITY OF NEVADA, RENO \\ NEW MEXICO STATE UNIVERSITY \\ OREGON STATE UNIVERSITY
}

\author{
UNIVERSITY OF OREGON \\ UNIVERSITY OF SOUTHERN CALIFORNIA \\ STANFORD UNIVERSITY \\ UNIVERSITY OF HAWAII \\ UNIVERSITY OF TOKYO \\ UNIVERSITY OF UTAH \\ WASHINGTON STATE UNIVERSITY \\ UNIVERSITY OF WASHINGTON
}

The Supporting Institutions listed above contribute to the cost of publication of this Journal, but they are not owners or publishers and have no responsibility for its content or policies.

Mathematical papers intended for publication in the Pacific Journal of Mathematics should be in typed form or offset-reproduced (not dittoed), double spaced with large margins. Please do not use built up fractions in the text of the manuscript. However, you may use them in the displayed equations. Underline Greek letters in red, German in green, and script in blue. The first paragraph must be capable of being used separately as a synopsis of the entire paper. In particular it should contain no bibliographic references. Please propose a heading for the odd numbered pages of less than 35 characters. Manuscripts, in triplicate, may be sent to any one of the editors. Please classify according to the scheme of Math. Reviews, Index to Vol. 39. Supply name and address of author to whom proofs should be sent. All other communications should be addressed to the managing editor, or Elaine Barth, University of California, Los Angeles, California 90024.

There are page-charges associated with articles appearing in the Pacific Journal of Mathematics. These charges are expected to be paid by the author's University, Government Agency or Company. If the author or authors do not have access to such Institutional support these charges are waived. Single authors will receive 50 free reprints; joint authors will receive a total of 100 free reprints. Additional copies may be obtained at cost in multiples of 50 .

The Pacific Journal of Mathematics is issued monthly as of January 1966. Regular subscription rate: $\$ 132.00$ a year (6 Vol., 12 issues). Special rate: $\$ 66.00$ a year to individual members of supporting institutions.

Subscriptions, orders for numbers issued in the last three calendar years, and changes of address should be sent to Pacific Journal of Mathematics, P.O. Box 969, Carmel Valley, CA 93924, U.S.A. Old back numbers obtainable from Kraus Periodicals Co., Route 100, Millwood, NY 10546.

The Pacific Journal of Mathematics ISSN 0030-8730 is published monthly by the Pacific Journal of Mathematics at P.O. Box 969, Carmel Valley, CA 93924. Application to mail at Second-class postage rates is pending at Carmel Valley, California, and additional mailing offices. Postmaster: Send address changes to Pacific Journal of Mathematics, P. O. Box 969, Carmel Valley, CA 93924.

PUBLISHED BY PACIFIC JOURNAL OF MATHEMATICS, A NON-PROFIT CORPORATION

Copyright $\odot 1984$ by Pacific Journal of Mathematics 


\section{Pacific Journal of Mathematics}

\section{Vol. 113, No. $2 \quad$ April, 1984}

Alan Adolphson, On the Dwork trace formula ...................257

Amos Altshuler and Leon Steinberg, Enumeration of the quasisimplicial

3 -spheres and 4-polytopes with eight vertices .................. 269

Kenneth R. Goodearl, Cancellation of low-rank vector bundles .......... 289

Gary Fred Gruenhage, Ernest A. Michael and Yoshio Tanaka, Spaces

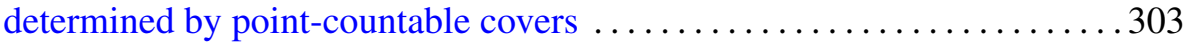

Charles Lemuel Hagopian, Atriodic homogeneous continua .......... 333

David Harbater, Ordinary and supersingular covers in characteristic $p$. . . 349

Domingo Antonio Herrero, Continuity of spectral functions and the lakes

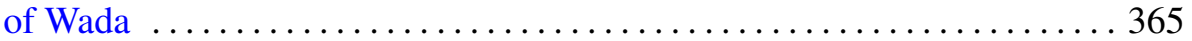

Donald William Kahn, Differentiable approximations to homotopy resolutions and framed cobordism ....................... 373

K. McGovern, On the lifting theory of finite groups of Lie type $\ldots \ldots \ldots . \ldots 383$

C. David (Carl) Minda, The modulus of a doubly connected region and the geodesic curvature-area method ............................. 395

Takuo Miwa, Complexes are spaces with a $\sigma$-almost locally finite base $\ldots . .407$

Ho Kuen Ng, Finitely presented dimension of commutative rings and modules

Roger David Nussbaum, A folk theorem in the spectral theory of

$C_{0}$-semigroups

J. S. Okon, Prime divisors, analytic spread and filtrations

Harold Raymond Parks, Regularity of solutions to elliptic isoperimetric problems

R. Sitaramachandra Rao and M. V. Subba Rao, Transformation formulae for multiple series

Daniel Ruberman, Imbedding punctured lens spaces and connected sums

Uri Srebro, Deficiencies of immersions 